DOI https://doi.org/10.36059/978-966-397-116-2/108-126

\title{
PUBLIC MONEY AS AN OBJECT OF CRITICAL INFRASTRUCTURE: THEORETICAL AND PRACTICAL ASPECT
}

\section{Zadyraka N. Yu.}

\section{INTRODUCTION}

Taking into account national trends of redistribution of a public product, a legal regime of public money appears to be one of key regulators of economic growth and public interest satisfaction as for national revenue growth.

According to the current legislation, one of the determinant objects of critical infrastructure is public finances being strategically significant for the functioning of economy and state safety, society and people ${ }^{1}$.

Studying the legal regime of public money we should mention that in practice there are many problems connected with the use of public property of such type. In particular, state police of resource limitation during public management and budget administration of money is not effective and high-qualitative enough; the intradepartmental information exchange is not well-organized; computerization of work with large volume data has not been finished; there are high corruption risks.

The drawbacks of public administration of public money given above can be seen when analyzing information system functioning as well the modules of public money use such as "E-data", "Prozorro", an electronic cabinet of tax payer, a single state web-portal of open access data, a single state register of people's declarations, authorized to execute state or local self-government functions, the System of electronic administration of VAT etc.

\section{Essential Features and Peculiarities of Administrative-Legal Regime of Public Property}

\footnotetext{
1 Про затвердження Порядку формування переліку інформаційно-телекомунікаційних систем об'єктів критичної інфраструктури держави: Постанова Кабінету Міністрів України від 23.08.2016 р. № 563. Офіиійинй вісник Украӥни. 2016. № 69 .С. 50. Ст. 2332. Код акту 82988/2016.
} 
In essential meaning, the legal regime of public property can be represented as an integral part of the state functions related to management. Such regime is based on the general principles, methods and forms of public management regarding the activities of competent public administration subjects and their officials in the interaction with private law subjects, as well as between themselves in the realization of their official duties, the regulation of a variety of objects and processes ${ }^{2}$. Accordingly, the peculiarities of the public property legal regime are determined by the content of tasks faced by the state and local selfgovernment as well as by peculiarities of the public administration activities within their competence, etc.

J. Wendel considers these properties through the prism of common law of public power, which includes four basic principles: the connection of public administration with the law; a special procedure for creation and implementation of tools for public administration activity; administrative justice as a form of resolving disputes and conflicts; liability of public administration for damages or other offences ${ }^{3}$.

The administrative legal nature of the public property legal regime appears as interaction of legal boundaries and appropriate institutional and functional tool that would guarantee a possibility for individuals to exercise their rights and obligations in relation to public property as well as specifics of public administration functioning in the specified domain which would reflect axiological features during the legal protection of public property. In addition, administrative and legal features of the above mentioned regime can be considered through organizational-managerial procedures for guaranteeing national security and law order.

We should specify that public property legal regime is the specific order of its subjects' functioning based on administrative law norms and aimed at overcoming negative phenomena in a relevant domain of public management ${ }^{4}$. Therefore, it is about axiological manifestation of administrative procedure optimization at implementing legal regimes and in certain types of public property.

2 Административное право: учеб. для вузов. 3-е изд., пересмотр. и доп. / Д.Н. Бахрах, Б.В. Россинский, Ю.Н. Старилов. Москва: Норма, 2007. 816 с.С. 482

${ }^{3}$ Ведель Ж. Административное право Франции / пер. с франц. Л.М. Энтина. Москва: Прогресс, 1973. 512 с. С. 65.

4 Адміністративне право України. Академічний курс: підруч. Т. 1. Загальна частина / заред. В.Б. Авер'янов. Київ: Видавництво «Юридична думка», 2004. 584 с. 
As O. O. Krestianov explains, centrally established tools of public administration through the imperative method of legal influence establish the procedure for the implementation of administrative-legal relations, in which traditionally a power subject and a subordinated person are in legally unequal position ${ }^{5}$. In fact, such position was dominant and acceptable until the institutionalization of the current state of legal opinion development on public property and selection of criteria for the formation of public property institution in the system of Common administrative law. Nevertheless, now it is worth supporting the doctrinal views where particular attention is paid to the specific nature of activity of subjects of law in various domains of state and public life, regulated and aimed at their strictly purposeful and functional activity in the area where additional funds are required to support the state system ${ }^{6}$. Such thesis indicates a static approach to the public property legal regime dealing with implementation of specific regulation (for certain types of public property), combining the tools of public administration activities, in particular, organization-oriented ones.

Along with that, taking into account the latest trends of public delegation of powers in the public administration field, the possibility of active and large-scale involvement of private law subjects in public property use, primarily at the local level, is not excluded at the present time. The legal regime of such public property, accordingly, is the normative defined rules of private law subjects' conduct, as well as the procedure for exercise of their powers under the specific conditions (situations) of ensuring and supporting the sovereignty and defense of the state, the interests of security and public order, specially created for this goal by public administration subjects ${ }^{7}$.

The provisions formulated, first of all, are relevant to the implementation of the border regime activity in the exercise of public property legal protection. The interpretation of the public property legal regime through combining the tools of public administration, determined by imperative and dispositive methods of legal regulation, taking into account the national specificity and the trans-boundary nature of subjects'

\footnotetext{
5 Крестьянинов А.А. Местотаможенныхрежимов в системеадминистративно-правовыхрежимов. Проблемизаконності. 1999. Вип. 37. С. 90-96. С. 91.

6 Тихомиров Ю.А. Административное право и процесс: полный курс. Москва: Изд-е г-на Тихомирова М.Ю., 2001. 652 с. С. 325.

${ }^{7}$ Розанов И.С. Административно-правовые режимы по законодательству Российской Федерации, их назначение и структура. Государство и право. 1996. № 9. С. 84-91. С. 85
} 
legal status in these legal relations, can be considered as the most acceptable.

The administrative-legal aspect of the public property legal regime is determined through the objective features of property, established at the normative level and implemented by using legal tools.

It is these aspects of the relevant legal regime that determine the outcomes of public administration tool influence on public relations in the legal protection of public property, which are typical of this administrative law institution and determine its implementation.

As a result, the doctrine formed an approach according to which the legal regime, in particular, of public property is regarded as a kind of social regime $^{8}$. According to I. Voronina, legal values serve as the core of law axiom field; they are in its basis and appear as tools for interpretation of legal reality, playing a system-forming role in implementing a structured, logical, holistic and effective model of public administration ${ }^{9}$. This is due to the fact the connection of legal regimes with large-scale social processes reveals when realizing the legal regimes of certain types of public property. It makes possible to effectively perform the tasks assigned to public administration in the implementation of public administration in a public property field. In addition, it needs to be clarified that economic, legal and social features of the legal regime of public property are changing phenomena being in a state of constant interaction and development. As a result, public interests and needs of participants in state and public life are met with the use of public property at the individual, group and general social levels through the mechanism of administrative-legal support and administrative procedures.

That is why the public property legal regime can be considered within the limits of social regime implemented in the system of legal measures and means defining specific interaction of permissions, prohibitions and positive liabilities. This legal category is a special, expanded block within the framework of legal tools extending its effect to the whole range of legal means which rational use in solving various specific needs, primarily, concerns the definition of appropriate legal

\footnotetext{
8 Мінка Т.П. Онтологічна характеристика правового режиму.Право $i$ суспільство. 2012. № 3. C. 123-127. C. 126.

9 Вороніна I. Соціально-правові цінності в системі соціально-політичного управління суспільством. Jurnalul juridicnaţional: teorieşipractică. 2016. № 1. Ч. 1. C. 5-8. С. 6, 8.
} 
regime for the public property legal protection, taking into account the essence of the latter.

The concept of "public property legal regime" can not be equated with the concept of a mechanism of legal provision and regulation. The legal regime is mostly a meaningful characteristic and is carried out through the above-mentioned mechanism, which is a general procedure, the process of action and exercise of the right through legal regulation ${ }^{10}$. Therefore, we fully support the doctrinal approach according to which such a mechanism can fully function through a holistic range of its constituent elements, namely: legal norms, legal relations, acts of exercise of rights and obligations ${ }^{11}$. Taking into account that the legal regime studied is implemented in normatively regulated relations in the field of public property use, the efficiency of its functioning depends on the proper "technology" and logical justification of relevant administrative procedures. The mechanism of administrative-legal support, regulation should determine the ways of implementation of regulatory measures in public administration of public property relations with the use of appropriate tools of public administration within the framework of specific administrative procedures.

In fact, the legal regime of public property through the mechanism of administrative law, regulation a priori includes the corresponding norms of law, based on the appropriate rules of conduct ${ }^{12}$. Thus, without legal norms, this legal regime can not be practically implemented, which creates conditions for the dialectical interaction of these legal categories. The public property legal regime as a manifestation of normative law can not be based solely on the object features of certain types of public property, but must establish the conduct, associated with them, of the subjects of relations in the field of public property use. In fact, depending on its goals and tasks, such legal regime of public property includes imperative - dispositive nature of fundamental legal regulators, in particular, legal norms.

10 Мінка Т.П. Онтологічна характеристика правового режиму. Право і суспільство. 2012. № 3. C. $123-127$. C. 126 .

11 Кравчук О.О. Управління державною власністю: адміністративно-правові засади: монографія. Київ: НТУУ «КПІ», 2013. 444 с. С. 102.

12 Вакарюк Л. Норма права та правовий режим: співвідношення понять. Підприємництвво, господарство і право. 2017. № 1. С. 171-176. С. 174. 
Taking into account the described features of the public property legal regime, the following should be attributed to such features: content and purpose, and also the structure of public property; the field of implementation and type of activities, in particular, the grounds for emergence and termination of the legal regime; the form of ownership and legal titles, in particular, the limits of their implementation by third parties; specific features; subjective dimension. In addition, we should specify that it is such set of properties of the public property legal regime that is based on the profile legal group and is determined by the ideological specificity of public management when it is used.

Consideration and study of the public property legal regime should be carried out in the aspect of influence of a law mechanism on public relations, but not on the management of human activity and its processes, etc. In this regard, the study of "legal regime" concept should be approached systematically, taking into account the diversity, dimension, "atmosphere" of law in which all elements of the legal system function and the unity of all its various elements reflecting the nature of law through the prism of its ontological connection with other elements of the legal system (legal principles, norms of law, legal relations, etc.) is ensured $^{13}$. In fact, the legal regime of public property is a component of a state regime on the basis of strict orderliness and systematic legal norms. The relevant legal category is characterized by multiple meaning, namely: a kind of "multi-layers" of adjacent legal categories and domination of such elements as the supremacy of law, the regime of public law order and disciplinary regime. The legal regime of public property, above all, is embodied in legal approaches, legal regulatory methodology, law-making and law-enforcement processes, and the legal consciousness of society. Therefore, one of the important indicators of such legal regime quality is legitimacy.

Individualization of the legal regime of public property is embodied in its essential features and in subject composition.

The legal regime is specified by using the concept of "legal regulation procedure", provided by a special combination of methods involved in its implementation. The relevant category is interpreted as a complex of legal means combined in a single structure, which ensures

13 Мінка Т.П. Онтологічна характеристика правового режиму. Право і суспільство. 2012. № 3. C. $123-127$. C. 126 . 
their effective use in solving special problems in order to choose the optimal legal solution for the task in question in accordance with the specifics of this task and the content of the public relations regulated ${ }^{14}$. In view of the above mentioned, it is necessary to take into account the organizational and legal means within the legal regime of public property as well, since the basis of such regime is not purely general permissions and prohibitions by nature, but based on them kinds (types) of legal regulation.

That is why the public property legal regime can be interpreted as generally permissive (in the context of general use) and actually permissive (in general, under the procedure).

At the same time, the current political and legal Ukrainian realities regarding the Operation of the joint forces in temporarily occupied territories in Donetsk and Luhansk regions lead to the formation of an additional set of peculiarities of the public property legal regime. So, according to S.O. Kuznychenko, in this aspect, it is about the necessity of priority consideration of the most severe extreme administrative-legal regime of a "martial law" as a special guarantee of ensuring the public interests of the state, society, a person both at the national level and at certain administrative-territorial entities ${ }^{15}$. The decisive criterion for democratization of the legal regime of public property is the principle of national sovereignty and legal provision of people's sovereignty through acts of direct expression of the will of private law subjects, first of all, citizens $^{16}$. The principle of national sovereignty and legal provision of people's power through acts of direct expression of private law subjects can be considered a decisive criterion for democratization of the legal regime of public property; it makes usurpation of public authority and/or its concentration within the body with monopoly or dominant position at the market impossible.

No less important to realize the impossibility of "mitigating" the administrative-legal regime of martial law in view of the lack of

\footnotetext{
${ }^{14}$ Общие дозволения и общие запреты в советском праве / С.С. Алексеев ; Ред.: Л.А. Плеханова. Москва: Юрид. лит., 1989. 288 с.; Алексеев С.С. Теория права. Москва: Издательство БЕК, 1995. 320 c. C. $185,243$.

15 Кузніченко С.О. Умови, порядок уведення та скасування правового режиму воєнного стану. Адміністративне право і процес. 2014. № 3(9). С. 253-263. С. 259.

16 Дроботова Т. Правові ознаки демократичного державно-правового режиму: актуальні питання систематизації. Юридична Україна. 2010. № 1. С. 34-40. С. 36; Мурашин Г.О. Акти безпосереднього народовладдя як джерела права України. Правова держава. 2007. Вип. 18. С. 156-162. С. 159; Pennock J.R. Democratic Political Theory. Princeton: Princeton U.P., 1979. 598 p. C. 441-445.
} 
appropriate procedures, so the legal regime of public property should meet the full range of legal requirements in the framework of implementation of this most strict legal regime. The peculiarities of emergence, change and termination of the specified legal relations are established through the discretion of public administration subjects authorized for such acts at the constitutional level. According to Clause 9, Part 1 of Art. 85; Clauses 19, 20, Part 1, Art. 106 of the Constitution of Ukraine, Art. 4, 11 of the Law of Ukraine "On the Fight against Terrorism", Art. 3, 5, 8 of the Law of Ukraine "On the Legal Regime of Martial Law" such subjects include: the Verkhovna Rada of Ukraine, the President of Ukraine, the National Security and Defense Council of Ukraine, the Security Service of Ukraine, the Ministry of Internal Affairs of Ukraine, the Ministry of Defense of Ukraine, specialized central executive authorities, the Council of Ministers of the Autonomous Republic of Crimea, local selfgovernment bodies, military commands, military administrations, etc. ${ }^{17}$.

In addition, it should be clarified that the regulatory nature of the public property legal regime determines the constituent elements and structure of such regime, reflecting the dynamic side of legal relations in the use and legal protection of public property. This can be realized through the modification of elements of the public property legal regime: legal methods and means, phenomena, etc. (norms of law, legal facts, legal ideology, legal awareness, legal principles, etc.). The legal regime mentioned highlights the external form of emergence, change, termination of the relevant public relations through the interaction of legal tools, methods of legal regulation. This ensures the proper dynamics of the public relations mentioned and determines the purpose of regulating the legal protection of public property and satisfying the public interests of participants in public relations in its use.

According to T.P. Minka, the elements of the public property legal regime are the following: objectified field of law validity is plurality of public relations defined in the social space, which constitute the subject of legal regulation; systematic, interconnected by logical links, a set of ways, methods and types of regulatory action of law to a certain set of public

\footnotetext{
${ }^{17}$ Конституція України: Закон від 28.06.1996 р. № 254к/96-ВР: із зм. і доп. станом на 30.09.2016 p. Офіційний вісник Украӥни. 2010. № 72/1. Спеціальний випуск. С. 15. Ст. 2598.; Про боротьбу 3 теороризмом: Закон України від 20.03.2003 р. № 638-IV: із зм. і доп. станом на 07.05.2016 р. Відомості Верховної Ради України. 2003. № 25. Ст. 180.; Про правовий режим воєнного стану: Закон України від 12.05.2015 р. № 389-VIII: із зм. і доп. станомна 09.07.2016 р. Відомості Верховної Ради Украӥни. 2015. № 28. Ст. 250.
} 
relations; certain socially significant result of law force, which is the purpose of legal regulation ${ }^{18}$.

In the field of legal regime implementation and in certain types of public property, it is necessary to distinguish such elements of the legal regime as an object (public property), subjects (public administration, subjects of private law - users), methods of legal regulation (imperativedispositive), the mechanism of administrative-legal support (normative regulation, legal relations, acts of law exercise and enforcement). The relevant elements of the public property legal regime reflect the meaningful aspects of legal protection of the latter, as well as its institutional and functional features.

It can be stated that the ontological, gnoseological and axiological dimensions of institutional-functional features of the public property legal regime allow ensuring the implementation of a normative component of the public property legal regime. The above mentioned legal category, although having some static features, is a priori dynamic and is determined by the current state of political, economic, social and other situations in the country. As a result, an appropriate regulatory paradigm for the use of certain types of public property is being formed, taking into account the trans-boundary and national dimensions of such legal regime implementation.

\section{Public Money as an Object of Critical Infrastructure}

We suggest starting the scientific analysis of public money legal regime with the consideration of the fact that it is distinguished by openness and dynamics of organizational-managerial and social-economic connections between its elements. This state of things is determined by the fact that public money is a legal category that is constantly developing under the conditions of volatility of financial resources, correlation of income and expenses, changes in demand and supply in the market conditions of innovative economy formation. Such volatility of the public money legal regime also determines its flexibility and diversity. Considering the national trends of redistribution of the social product, the legal regime mentioned appears as one of the key regulators of economic

\footnotetext{
${ }^{18}$ Мінка Т.П. Правовий режим у теорії адміністративного права. Адміністративне право $i$ процес. 2013. № 2 (4). C. 23-29. С. 26.
} 
development and satisfaction of public interest in the national income growth.

At the same time, one should pay attention to the fact that in European countries the public money legal regime is regulated at the constitutional level. In particular, the Constitution of the Federal Republic of Germany presents a section on "Finance" on income and expenses of budgets ${ }^{19}$. In the Constitution of Poland there is a certain section "Public Finances"20. Article 119 of the Constitution of Italy deals with public money of the state, provinces and communes ${ }^{21}$. Article 70 of the Constitution of France defines the procedure of public money use as for cooperation with the state, the Parliament and the Economic, Social and Ecologic Council ${ }^{22}$.

Although the Constitution of Ukraine enshrines legal category of "finances"23 (Art. 140 of the Basic Law), but the laws provide the definition of concepts of state finances and public money (public finances). So, speaking on this subject, it is necessary to refer to the provisions of Clause 2 of Part 1 of Art. 1 of the Law of Ukraine "On Openness of Use of Public Funds"24, Section 2 of the "Strategy of Reforming the Public Finance Management System"25, Clause 1, 5 of Section 3 of the Strategy for Sustainable Development "Ukraine-2020"26 Clauses 90, 95, 156 of Plan of measures for its realization ${ }^{27}$. In fact, legal categories used in the provisions given are associated with the money

19 Конституція Федеративної Республіки Німеччини. URL: http://legalportal.am/download/ constitutions/83ru.pdf (датазвернення: 02.05.2019.).

${ }^{20}$ Конституція Польської Республіки. URL: http://blog.vladey.com.ua/konstituciya-polsko\%D1\%97respubliki-ukra\%D1\%97nskoyu-movoyu/ (датазвернення: 02.05.2019.).

21 Конституція Італії. URL: http://lawers-ssu.narod.ru/subjects/constzs/italy.htm (дата звернення: 02.05.2019.).

22 Конституція Франції. URL: http://www.conseil-constitutionnel.fr/conseilconstitutionnel/root/ bankmm/constitution/constitutionrusseversionaout2009.pdf (датазвернення: 02.05.2019).

${ }^{23}$ Конституція України: Закон від 28.06.1996 р. № 254к/96-ВР: із зм. і доп. станом на 30.09.2016 p. Офіційний вісник України. 2010. № 72/1. Спеціальний випуск. С. 15. Ст. 2598.

${ }^{24}$ Про відкритість використання публічних коштів: Закон України від 11.02.2015 р. № 183-VIII: із зм. і доп. станом на 30.09.2015 р. Відомості Верховної Ради Украӥни. 2015. № 16. С. 921.Ст. 109.

25 Просхвалення Стратегії реформування системи управління державними фінансами на 2017 2020 роки: Розпорядження Кабінету Міністрів України № 142-р від 08.02.2017 р. Офіційиий вісник Украӥни. 2017. № 23. С. 61.Ст. 659.

26 Про Стратегію сталого розвитку «Україна - 2020»:Указ Президента України № 5/2015 від 12.01.2015 р. Офіційний вісник Украӥни. 2015. № 4. С. 8. Ст. 67.

27 Про затвердження плану заходів з виконання Програми діяльності Кабінету Міністрів України та Стратегії сталого розвитку «Україна-2020» у 2015 році: Розпорядження Кабінету Міністрів України від 04.03.2015 р. № 213-p: із зм. і доп. станомна 06.07.2016 p. URL: http://zakon2.rada.gov.ua/laws/show/ 213-2015-р (дата звернення: 02.05.2019.). 
accumulated in the certain funds, the rights for which are owned by the state and territorial community.

It can be stated that public money is associated with the categories of public administration using financial resources to meet public interest, public needs. In fact, it is about public financial capital: funds of the state budget of Ukraine and local budgets, credit resources, funds of state banks and public law funds, state special purpose funds, as well as public money received on the results of the economic activity of private law entities. As for doctrinal interpretation of public money, then this concept is considered comprehensively:

- As a subject of legal regulation - socio-economic relations appearing in the process of formation, distribution (redistribution) and $u_{\mathrm{use}}^{28}$ of public centralized and decentralized money of funds required for the functioning of public administration subjects ${ }^{29}$;

- As an object of legal relations - a tool of public administration at carrying out its activity ${ }^{30}$; an object of financial activity admitted to economic turnover ${ }^{31}$; monetary funds of the state, state-territorial and municipal entities, enterprises, institutions, organizations and other subjects of economic activity, used for material provision of society needs and production development ${ }^{32}$.

Speaking about the public money legal regime it is worth paying attention to controversial aspects of use of relevant public finances in judicial practice. Thus, judicial cases, considered and resolved within administrative jurisdiction, are connected to, primarily, controversial issues of money placement and inaction of public law funds. We can give as an example the cassation proceedings opened by the High Administrative Court of Ukraine, as for:

- The issue of an unlawful administrative act and not placement of public funds according to the claims of a private law subject (additional liability company "Zhytlobud-2") to authorized public administration subjects, legal entities of public law and an official of a public law fund,

28 Бардаш С.В., Баранюк Ю.Р. Поняття і склад публічних фінансів як об'єкта державного фінансового аудита. Науковий вісник Ужгородського наџіонального університету. 2016. Вип. 6(1). С. 34-37 (Серія: Міжнародні економічні відносини та світове господарство). С. 36.

${ }^{29}$ Воронова Л.К. Фінансове право України: підруч. Київ: Прецедент: Моя книга, 2006.448 с. С. 7.

30 Заверуха О.Б. Бюджетні повноваження органів місцевого самоврядування в Україні: дис. ... канд. юрид. наук: 12.00.07 / Чернівецький держ. ун-т ім. Ю. Федьковича. Чернівці, 2001. 236 с. С. 19.

${ }^{31}$ Головенко О. Теоретичні засади застосування категорії «публічні фінанси» у фінансовому праві. Теорія і практика інтелектуальної власності. 2011. № 3. С. 73-78. С. 75.

${ }^{32}$ Сисуари В.В. Финансы как объект правового регулирования. Финансовое право. 2005. № 3. С. 4-5. 
in particular, with the participation of third parties (the Department of state registration of property rights to real estate of Kharkiv city department of justice, Department of registration of Kharkiv city council, state enterprise "National Information Systems", an official of the Deposit Guarantee Fund for Individuals for the liquidation of Public Joint-Stock Company "BANK National Credit", with the participation of third parties - Limited Liability Company "KM-Holding", Public Joint Stock Companies "Volynbakalia", "Company "Rise") ${ }^{33}$;

- Unlawful inaction of the authorized person of public law fund in the aspect of not approval of a general register of depositors, who have the right to have a compensation of funds on their deposits, not inclusion to the list of depositors of a person having the powers to have compensation of funds, as well as inaction concerning public money payment in the amount established - in particular, concerning inaction of the official of the Deposit Guarantee Fund of Individuals in the part of money compensation on deposits of Public Joint Stock Company "European Gas Bank" by funds of the public law fund mentioned under the agreement on bank deposit (account) ${ }^{34}$.

Evaluating the above mentioned, we would like to emphasize that in order to resolve disputes when using public money as public property, it is necessary to refer to three basic theories of economic nature: the theory of public choice in a democratic environment (J. Buchanan); the theory of social welfare, the decisive meaning of which states that changes in the financial domain are appropriate only when the welfare of individual social groups improves without the deterioration of others (V. Pareto); the theory of fiscal exchange "taxes-good" (K. Wicksell, E. Lindahl, J. Buchanan $)^{35}$.

Optimization of the process of legal regime implementation of public money should relate to the normative, institutional, organizational and technological principles of modernization of public management. This, in turn, means improving the legal grounds, in particular, at the

\footnotetext{
33 Ухвала Вищого адміністративного суду України від 19.07.2016 р. № K/800/16402/16. URL: http://reyestr.court.gov.ua/Review/59202527 (дата звернення: 02.05.2019.); Ухвала Вищого адміністративного суду України від 24.01.2017 р. № K/800/16402/16, K/800/17208/16. URL: http://reyestr.court.gov.ua/Review/64507344 (дата звернення: 02.05.2019.).

34 Ухвала Вищого адміністративного суду України від 03.03.2016 р. № K/800/46854/15. URL: http://reyestr.court.gov.ua/Review/56645725 (дата звернення: 02.05.2019.).

35 Пахоляк У. Шляхи покращення управління публічними фінансами в сучасних умовах. Матеріали міжнародної науково-практичної конференції студентів $і$ молодих учених "Соціальноекономічні аспекти розвитку економіки», 27-28 квітня 2017 р. Т.: ТНТУ, 2017. С. 32-35. С. 32.
} 
constitutional level in relation to the provisions on public finances, in the use of certain type of public property as for the development of strategic standardization and methodological procedural dimension, macroeconomic forecasting and medium-term planning; institutional optimization for strengthening cooperation between public administration subjects, as well as with private law subjects, which is ensured, in particular, by monitoring and auditing the effectiveness of the public money use; organizational changes in conducting information and education campaigns for relevant civil servants and civil society representatives; technological modernization of information systems, analytical modules, portals, services of public money management, strengthening of software and technical security.

The outcomes of the described ways of improving the public money legal regime can be clearly seen through the public management of the use of the relevant type of public property. In addition, as pointed out by P. Schroeder, it is necessary to distinguish the concept of public management as a regulatory activity of public administration from the category of "administration", which manifests itself in the field of public finance $^{36}$. Thus, the legal regime of public money should be based on the following administrative and financial features: the purposefulness of activities of public administration subjects, expressed in the provision of goal achievement in the field of use of public money, in particular through a single web-portal (axiological orientation); the secondary nature of legislative activity, the lawfulness on the basis and for the implementation of legislative norms in order to fulfill the requirements of law; regulation of competence, expressed in the presence of procedural and legal norms (public-procedural regulatory basis); regular, permanent nature of activity (persistency); the existence of authority in the subjects of public administration; management with the purpose of realization of the state financial policy and strengthening of discipline (managerial dimension) ${ }^{37}$. It is the goals and objectives of the public money legal regime that determine the dimension of specific forms of public management in the use of public property of the type mentioned.

\footnotetext{
${ }^{36}$ Шрьодер П. Нове публічне адміністрування, або як досягнути ефективного врядування?. Київ: Вид-во «Заповіт», 2008. 76 с.

37 Клімова С.М. Адміністрування як правова форма управління у сфері публічних фінансів. Науковий вісник Херсонського державного університету. 2016. Вип. 5. Т. 2. С. 52-55. С. 55.
} 
It is worth noting that it is essential to develop effective and efficient legislation to implement the legal regime mentioned above. First of all, it is about the need of procedural component consolidation of normativelegal framework for implementation of the state policy on the public money use. In particular, the main focus should be on public financial as well as administrative procedures in the field of public management and administration of such public property. Therefore, it is necessary to regulate this area in a comprehensive manner in relation to most of the acts performed by public administration subjects, first of all, in terms of unification of the regulatory basis for the implementation of administrative procedures for public management in the use of public money, budget administration.

\section{CONCLUSIONS}

Carrying out the legal protection of public property, the legal regime substantially and contextually covers the subject, specific interaction of legal methods and tools of public administration activity or the implementation of legal procedures in general, as well as the purpose of legal regulation. Such legal regime is systematic, opened, multilayered and has a variable internal structure.

It has been established that there are general and specific grounds for the emergence of a public property legal regime. Thus, the special grounds are connected with the emergence of legal facts in relation to the exceptional ability of public administration subjects to acquire rights to public property. Instead, all other grounds have a general nature.

The factors of influence on the process of termination of public property legal regime by institutional and functional criteria in the general dimension, as well as on the basis of legal facts (special grounds for termination of the corresponding legal regime) are specified.

The necessity of creating a single legal framework for the effective and transparent implementation of the public money legal regime, first of all, on the basis of digitalization of procedural-procedural dimension through a single portal for the use of public money is justified. Not less important in this meaning is to establish the mechanism and forms of activity of relevant public administration subjects and private law subjects regarding the planned and actual use of this type of public property. 
It is emphasized that the public money legal regime provides for the relative independence of state and municipal finances providing the unity of the public administration system by the national financial and credit, monetary system. Such public money has, first of all, a strong social purpose within budgets, extra-budgetary and decentralized funds.

As a result, state and social public interests of the national level are met in parallel with the territorial public interest in creating conditions for the sustainable development of civil society and the state by taking into account the needs of public management and supervision through the generalization of personal and group interests within the financial system, in particular through such a tool of electronic democracy, as public budgets (participation budgets).

\section{SUMMARY}

The article deals with the issues connected with the use of public money as objects of critical infrastructure. In particular, the inefficiency of state policy in public management and public administration of public money, as well as the imperfection of intra-departmental exchange of information and the incomplete computerization of work with large volumes of data, is emphasized. The following drawbacks of public management of public money can be seen in the analysis of functioning of information-analytical systems and modules on the use of public money such as "E-data", "Prozorro" and others.

The concept and essential features of the public property legal regime in general and its constituent element such as public finances are described in detail. It is emphasized that the Operation of the joint forces in temporarily occupied territories in Donetsk and Luhansk regions leads to the formation of an additional set of peculiarities of the public property legal regime.

The author attracts attention to the fact that in resolving disputes during public money use as public property it is necessary to refer to three basic theories: the theory of public choice in a democratic environment; the theory of social welfare and the theory of fiscal exchange "taxes-good". 


\section{REFERENCES}

1. Административное право: учеб. для вузов. 3-е изд., пересмотр. и доп. / Д.Н. Бахрах, Б.В. Россинский, Ю.Н. Старилов. Москва: Норма, 2007. 816 c.

2.Адміністративне право України. Академічнийкурс: підруч. T. 1. Загальна частина / заред. В.Б. Авер'янов. Київ: Видавництво «Юридична думка», 2004. 584 с.

3. Алексеев С.С. Теория права. Москва: Издательство БЕК, 1995. $320 \mathrm{c}$.

4. Бардаш С.В., Баранюк Ю.Р. Поняття i склад публічних фінансів як об'єкта державного фінансового аудита. Науковий вісник Ужгородського національного університету. 2016. Вип. 6(1). C. 34-37 (Серія: Міжнародні економічні відносини та світове господарство).

5. Вакарюк Л. Норма права та правовий режим: співвідношення понять. Підприємництво, господарство $i$ право. $2017 . \quad$ № 1. C. 171-176.

6. Ведель Ж. Административное право Франции / пер. с франц. Л.М. Энтина. Москва: Прогресс, 1973. 512 с.

7. Вороніна I. Соціально-правові цінності в системі соціальнополітичного управління суспільством. Jurnalul juridicnaţional: teorieşipractică. 2016. № 1. Ч. 1. С. 5-8.

8. Воронова Л.К. Фінансове право України: підруч. Київ: Прецедент: Моя книга, 2006. 448 с.

9. Головенко О. Теоретичні засади застосування категорії «публічні фінанси» у фінансовому праві. Теорія $i$ практика інтелектуальної власності. 2011. № 3. С. 73-78.

10. Дроботова Т. Правові ознаки демократичного державноправового режиму: актуальні питання систематизації. ЮридичнаУкраїна. 2010. № 1. С. 34-40.

11. Заверуха О.Б. Бюджетні повноваження органів місцевого самоврядування в Україні: дис.... канд. юрид. наук: 12.00.07 / Чернівецькийдерж. ун-т ім. Ю. Федьковича. Чернівці, 2001. $236 \mathrm{c}$.

12. Клімова С.М. Адміністрування як правова форма управління у сфері публічних фінансів. Науковий вісник Херсонського державного університету. 2016. Вип. 5. Т. 2. С. 52-55., с. 55 
13. Конституція Iталії. URL: http://lawers-ssu.narod.ru/subjects/ constzs/italy.htm (дата звернення: 02.05.2019.).

14. Конституція Польської Республіки. URL: http://blog.vladey.com.ua/konstituciya-polsko\%D1\%97-respublikiukra\%D1\%97nskoyu-movoyu/ (дата звернення: 02.05.2019.).

15. Конституція України: Закон від 28.06.1996 р. № 254к/96-ВР: із зм. і доп. станом на 30.09.2016 р. Офіиійний вісник України. 2010. № 72/1. Спеціальний випуск. С. 15. Ст. 2598.

16. Конституція Федеративної Республіки Німеччини. URL: http://legalportal.am/download/constitutions/83ru.pdf (дата звернення: 02.05.2019.).

17. Конституція Франції. URL: http://www.conseilconstitutionnel.fr/conseilconstitutionnel/root/bankmm/constitution/constit utionrusseversionaout2009.pdf (дата звернення: 02.05.2019).

18. Кравчук О.О. Управління державною власністю: адміністративно-правові засади: монографія. Київ: НТУУ «КПІ», 2013. $444 \mathrm{c}$.

19. Крестьянинов А.А. Место таможенных режимов в системе административно-правовых режимов. Проблеми законності. 1999. Вип. 37. С. 90-96.

20. Кузніченко С.О. Умови, порядок уведення та скасування правового режиму воєнного стану. Адміністративне право і процес. 2014. № 3(9). C. 253-263.

21. Мінка Т.П. Онтологічна характеристика правового режиму. Право і суспільство. 2012. № 3. С. 123-127.

22. Мінка Т.П. Правовий режим у теорії адміністративного права. Адміністративне право і прощес. 2013. № 2 (4). С. 23-29.

23. Мурашин Г.О. Акти безпосереднього народовладдя як джерела права України. Правова держсава. 2007. Вип. 18. С. 156-162.

24. Общие дозволения и общие запреты в советском праве / С.С. Алексеев ; Ред.: Л.А. Плеханова. Москва: Юрид. лит., 1989. $288 \mathrm{c}$.

25. Пахоляк У. Шляхи покращення управління публічними фінансами в сучасних умовах. Матеріали міжнародної науковопрактичної конференції студентів $і$ молодих учених «Соціальноекономічніаспектирозвиткуекономіки», 27-28 квітня 2017 р. Т.: THTУ, 2017. C. 32-35. 
26. Проборотьбу з теороризмом: ЗаконУкраїнивід 20.03.2003 p. № 638-IV: із зм. і доп. станомна 07.05.2016 р. Відомості Верховної Ради Украӥни. 2003. № 25. Ст. 180.

27. Про відкритість використання публічних коштів: Закон України від 11.02 .2015 p. № 183-VIII: із зм. і доп. станомна 30.09.2015 р. Відомості Верховної Ради України. 2015. № 16. С. 921. Ст. 109.

28. Про затвердження плану заходів 3 виконання Програми діяльності Кабінету Міністрів України та Стратегії сталого розвитку «Україна-2020» у 2015 році: Розпорядження Кабінету Міністрів України від 04.03.2015 p. № 213-p: із зм. і доп. станомна 06.07.2016 p. URL: http://zakon2.rada.gov.ua/laws/show/213-2015-p (датазвернення: ).

29. ПрозатвердженняПорядкуформування переліку інформаційно-телекомунікаційних систем об'єктів критичної інфраструктури держави: Постанова Кабінету Міністрів України від 23.08.2016 р. № 563. ОфічійнийвісникУкраӥни. 2016. №69.С. 50. Ст. 2332. Кодакту 82988/2016.

30. Про правовий режим воєнного стану: Закон України від 12.05 .2015 p. № 389-VIII: із зм. і доп. станомна 09.07 .2016 p. Відомості Верховної Ради України. 2015. № 28. Ст. 250.

31. Про Стратегію сталого розвитку «Україна - 2020»: Указ Президента України № 5/2015 від 12.01.2015 р. Офіційний вісник України. 2015. № 4. С. 8. Ст. 67.

32. Просхвалення Стратегії реформування системи управління державними фінансами на 2017-2020 роки: Розпорядження Кабінету Міністрів України № 142-p від 08.02.2017р.Офіџійний вісник Украӥни. 2017. № 23. С. 61. Ст. 659.

33. Розанов И.С. Административно-правовые режимы по законодательству Российской Федерации, их назначение и структура. Государство и право. 1996. № 9. С. 84-91.

34. Сисуари В.В. Финансы как объект правового регулирования. Финансовое право. 2005. № 3. С. 4-5.

35. Тихомиров Ю.А. Административное право и процесс: полный курс. Москва: Изд-е г-на Тихомирова М.Ю., 2001. 652 с.

36. Ухвала Вищого адміністративного суду України від 03.03.2016 p. № K/800/46854/15. URL: http://reyestr.court.gov.ua/ Review/56645725 (датазвернення: 02.05.2019.). 
37. Ухвала Вищого адміністративного суду України від 19.07.2016 p. № K/800/16402/16. URL: http://reyestr.court.gov.ua/ Review/59202527(датазвернення: 02.05.2019.).

38. Ухвала Вищого адміністративного суду України від 24.01.2017 p. № K/800/16402/16, K/800/17208/16. URL: http://reyestr.court.gov.ua/Review/64507344(дата звернення: 02.05.2019.).

39. Шрьодер П. Нове публічне адміністрування, або як досягнути ефективного врядування? Київ: Вид-во «Заповіт», 2008. $76 \mathrm{c}$.

40. Pennock J.R. Democratic Political Theory. Princeton: Princeton U.P., 1979. 598 p.

\section{Information about the author: Zadyraka N. Yu. $\mathrm{PhD}$ in Law Science,} Associate Professor at the Administrative Law Department, Faculty of Law, Taras Shevchenko National University of Kyiv 